GRASAS Y ACEITES 71 (3)

July-September 2020, e372

ISSN-L: 0017-3495

https://doi.org/10.3989/gya.0462191

\title{
GC-MS analysis of volatiles in cinnamon essential oil extracted by different methods
}

\author{
T. Yu, H. Yao, S. Qi and J. Wang ${ }^{凶}$ \\ South China University of Technology, School of Food Science and Engineering, Wushan Road 381, Guangzhou, 510641, China \\ ${ }^{\square}$ Corresponding author: wangjuan@scut.edu.cn
}

Submitted: 30 April 2019; Accepted: 19 September 2019; Published online: 26 August 2020

\begin{abstract}
SUMMARY: Cinnamon essential oil (CEO) was extracted by three different methods: steam distillation (SD), ultrasound-assisted steam distillation (UASD) and microwave-assisted steam distillation (MASD). The volatiles in CEO were separated and identified by gas chromatography-mass spectrometry (GC-MS), and the differences in volatiles among the three different methods were further analyzed through principal component analysis. The results showed that 36 individual volatile components were present in the CEO from the three different methods. In general, the numbers of aldehydes, esters, alcohols, terpenes, aromatics and ketones were 6, 3, 7, 17, 2, and 1 , respectively. The most abundant volatile component was determined to be cinnamic aldehyde. The content of total cinnamic aldehydes, which determines the price of CEO, was the highest among the three methods in the UASD sample $(85.633 \%)$. Moreover, the highest yield $(8.33 \%$ ) of essential oil was extracted by the UASD method. Therefore, UASD was the best way for CEO extraction in this research and was recommended for future industrial applications.
\end{abstract}

KEYWORDS: Cinnamic aldehyde; Cinnamon essential oil; Extraction method; GC-MS; Volatiles

RESUMEN: Análisis de volátiles mediante GC-MS de aceites esenciales de canela extraídos por diferentes métodos. El aceite esencial de canela (AEC) se extrajo mediante tres métodos diferentes: destilación al vapor (DV), destilación al vapor asistida por ultrasonido (DVAU) y destilación al vapor asistida por microondas (DVAM). Los volátiles del AEC se separaron e identificaron mediante cromatografía de gases-espectrometría de masas (GC-MS), las diferencias de los volátiles entre los tres métodos se analizaron adicionalmente a través del análisis de componentes principales. Los resultados mostraron la presencia de 36 componentes volátiles en el AEC mediante los tres métodos diferentes. En general, el número de aldehídos, ésteres, alcoholes, terpenos, aromáticos y cetonas presentes fue de 6, 3, 7, 17, 2 y 1, respectivamente. Se determinó que el componente volátil más abundante era el aldehído cinámico. El contenido de aldehído cinámico total, el cual decide el precio del AEC, en la muestra de DVAU (85,633\%), fue el más alto entre tres métodos. Además, el mayor rendimiento $(8,33 \%)$ de aceite esencial se encontró mediante el método DVAU. Por lo tanto, DVAU fue la mejor forma de extracción de AEC en esta investigación y se recomienda en futuras aplicaciones industriales.

PALABRAS CLAVE: Aceite esencial de canela; Aldehído cinámico; GC-MS; Método de extracción; Volátiles.

ORCID ID: Yu T https://orcid.org/0000-0003-3700-8199, Yao H https://orcid.org/0000-0002-5459-2289, Qi S https:// orcid.org/0000-0002-6578-1464, Wang J https://orcid.org/0000-0002-5015-0176

Citation/Cómo citar este artículo: Yu T, Yao H, Qi S, Wang J. 2020. GC-MS analysis of volatiles in cinnamon essential oil extracted by different methods. Grasas Aceites 71 (3), e372. https://doi.org/10.3989/gya.0462191

Copyright: (C2020 CSIC. This is an open-access article distributed under the terms of the Creative Commons Attribution 4.0 International (CC BY 4.0) License. 


\section{INTRODUCTION}

Cinnamon (Cinnamomum cassia Presl), a tropical evergreen tropical tree from the Lauraceae family, is widely distributed in Southeast Asia (Chang, Chen, Chang, 2010). As the biggest producer of cinnamon in the world, China has produced more than $80 \%$ of the cinnamon in the world, especially in the Guangdong and Guangxi provinces, which accounted for $95 \%$ of the total production in China ( $\mathrm{Li}$ et al., 2013). Cinnamon is often used as a traditional medicine in India and China due to its unique medicinal and aromatic values, and it is mainly used for the treatment of anorexia, heart disease, intestinal disease and helminthic infections. Cinnamon bark and cinnamon essential oil (CEO) are included in pharmacopoeias in many countries (India, Britain, China, Australia, Belgium, France, Germany, Hungary, Japan, Portugal and Switzerland), and they have also been used as food additives, condiments and flavoring agents due to their carminative, antioxidant and preservative properties (Nabavi et al., 2015). Rui et al., (2009) found that the number of volatiles identified in Cinnamomum cassia, Cinnamomum zeylanicum, Cinnamomum tamala, Cinnamomum burmannii, Cinnamomum pauciflorum were 22, 22, 13, 6 and 21 , respectively. Cinnamaldehyde, with good inhibitory effects on many food spoilage microorganisms, is the characteristic volatile component of CEO, which exists in all kinds of cinnamon species (Matan et al., 2006). In addition, in international trade, the higher the content of total cinnamic aldehydes in CEO, the higher price of CEO is. Therefore, as the main volatile, the cinnamic aldehyde level should be obtained to the greatest extent during the extracting procedure of CEO.

Until now, the hydrodistillation, steam distillation (SD), steam and water distillation, maceration, hollow distillation, and expression methods have been widely used to obtain essential oils or extracts from plant materials (Jeyaratnam et al., 2016). SD is a promising extraction method as its outstanding advantages such as solvent-free, easy to operate, and safe. In addition, SD can prevent volatile oils from decomposition because steam is able to reduce the boiling point of the oils (Wong et al., 2014).

Furthermore, the ultrasound-assisted and microwave-assisted extraction techniques are also recognized as efficient methods with a short extraction time, increased yield and good quality (Cravotto et al., 2008). Azlina et al., (2013) extracted gaharu essential oil via ultrasonic assisted steam distillation (UASD), which increased extraction efficiency and reduced production costs. Microwave-assisted steam distillation (MASD) combines the advantages of both conventional and modern technologies, and is probably the leading technology in the essential oil production industry. Golmakani and Rezaei (2010) increased extraction efficiency by 4 times using MASD compared to the traditional SD method during the extraction of Zataria multiflora essential oil.

At present, the SD method is used to produce CEO in factories. Since its disadvantages are low yield of essential oil, low total cinnamic aldehyde content in the products and high energy consumption, it is necessary to find a new extraction method with higher yield and cinnamic aldehyde content. In the present research, The UASD and MASD methods were used for comparison with the traditional SD method in the yield of essential oil and cinnamic aldehyde content as determined by Gas chromatography- mass spectrometry (GC-MS).

\section{MATERIALS AND METHODS}

\subsection{Materials}

Cinnamon (Cinnamomum cassia Presl) was collected from Yunfu City, (Guangdong Province, China) and naturally air-dried, then ground and screened into powder using a shaker with a 40-mesh sieve, and placed in a desiccator prior to use. Three samples were prepared for each treatment, for a total of 9 CEO samples.

\subsection{Preparation of cinnamon essential oil by SD}

Each cinnamon sample $(150 \mathrm{~g})$ was placed in a glass distillation flask $(3.6 \mathrm{~L})$. According to our former optimized process, where the power of a steam generator (self-made) was set at $600 \mathrm{~W}$, and the vapor generated in the steam generator passed through the material for 2 hours, the CEO was separated from the mixture of water-oil by static stratification.

\subsection{Preparation of cinnamon essential oil by UASD}

The ultrasonic pre-treatment process was carried out in an ultrasonic cell crusher (JY92-IIN model, SCIENTZ, China). Each cinnamon sample (150 g) was put in a stoppered flask, and subjected to ultrasonic processing under settled conditions. Based on our former optimized process, ultrasonic power of $250 \mathrm{~W}$ and distillation temperature of $40{ }^{\circ} \mathrm{C}$ with a water to raw material ratio (w/w) of (16:1) for $25 \mathrm{~min}$ were applied. Then the samples were placed in glass distillation flasks (3.6 L) and the vapor generated in the steam generator passed through the material for $2 \mathrm{~h}$, with the same conditions as SD.

\subsection{Preparation of cinnamon essential oil by MASD}

The microwave pre-treatment process was carried out in a microwave oven (P70D20N1P-G5 (W0) model, SCIENTZ, China). The essential oil 
was obtained by MASD extraction according to our former optimized processing method. Briefly, each cinnamon sample $(150 \mathrm{~g})$ was put in a plugged glass flask, and subjected to microwave under settled conditions: a power of $400 \mathrm{~W}$ with a water to raw material ratio $(\mathrm{w} / \mathrm{w})(16: 1)$ for $5 \mathrm{~min}$. Then, the samples were put in the glass distillation flask $(3.6 \mathrm{~L})$ and the steam generated in the steam generator passed through the material for $2 \mathrm{~h}$ with the same parameters as $\mathrm{SD}$.

\subsection{The yield calculation}

The yield of CEO was calculated by eq. 1 .

Yield $(\%)=[$ the weight of CEO $(\mathrm{g}) /$ the weight of cinnamon sample $(\mathrm{g})] \times 1000 \%$

\subsection{GC-MS analysis}

The volatile components were analyzed by GC-MS (7890A-5975C, Agilent, USA) using a HP-5 capillary column (The column was 30 meters in length with an inner diameter of $0.25 \mathrm{~mm}$ and $0.25 \mu \mathrm{m}$ thickness) with $95 \%$ methyl and 5\% dimethyl poly siloxane as the stationary phase. Helium was used as the carrier gas at a flow rate of $1.0 \mathrm{~mL} / \mathrm{min}$. The split ratio was 30:1 and the injected quantity was $0.2 \mu \mathrm{L}$. The program temperature conditions were: the oven temperature was maintained at $40{ }^{\circ} \mathrm{C}$ for $5 \mathrm{~min}$, increased to $260^{\circ} \mathrm{C}$ at a rate of $3{ }^{\circ} \mathrm{C} / \mathrm{min}$ and held for $10 \mathrm{~min}$, and then increased to $280^{\circ} \mathrm{C}$ at $10^{\circ} \mathrm{C} / \mathrm{min}$ and maintained for $2 \mathrm{~min}$. The mass spectrometer was operated in the electron ionization mode at $70 \mathrm{eV}$ and electron multiplier voltage was adopted at $1823.5 \mathrm{~V}$. The ion source was established at a temperature of $230{ }^{\circ} \mathrm{C}$, the maximum temperature was set at $250^{\circ} \mathrm{C}$, and the quadrupole rod temperature was employed at $150{ }^{\circ} \mathrm{C}$, with the maximum temperature of $200{ }^{\circ} \mathrm{C}$. The mass range for this scanning was $50.0-$ $550.0 \mathrm{amu}$. All volatile components were identified by matching the recorded mass spectra with the standard mass spectra provided by NIST11.L database.

\subsection{Principal component analysis (PCA)}

PCA was performed by SPSS 21.0 (SPSS Inc., Chicago, IL, USA) to identify the most important volatile components in the samples extracted by the three different methods explained above. $p<0.05$ was considered statistically significant.

\section{RESULTS AND DISCUSSION}

\subsection{The yield of essential oil}

According to Table 1, the UASD method showed the highest yield of CEO, followed by MASD. And the lowest yield was found for the SD method.
TABLE 1. The yield of Cinnamon essential oil (CEO)*.

\begin{tabular}{lc}
\hline Extraction Method & Yield of CEO (\%) \\
\hline Steam distillation (SD) & $3.91 \pm 0.09^{\mathrm{a}}$ \\
$\begin{array}{l}\text { Ultrasound-assisted steam } \\
\text { distillation (UASD) }\end{array}$ & $8.33 \pm 0.02^{\mathrm{c}}$ \\
$\begin{array}{l}\text { Microwave -assisted steam } \\
\text { distillation (MASD) }\end{array}$ & $5.53 \pm 0.03^{\mathrm{b}}$ \\
\hline
\end{tabular}

*Different superscript letters mean significant difference $(\mathrm{p}<0.05), \mathrm{n}=3$.

Significant differences in yield were seen among the three methods. The cell wall may have been damaged by the ultrasonic treatment so that the CEO was able to escape more easily; microwave treatment was beneficial for CEO extraction, but the effect was not as good as the ultrasonic treatment.

\subsection{Volatiles separated and identified by GC-MS}

The volatile components collected from the different methods were separated and identified by GC-MS. Total ionisation chromatograms (TIC) of the volatile constituents of CEO extracted via $\mathrm{SD}$, UASD and MASD are shown in Figure $1(\mathrm{a}-\mathrm{c})$ and the identification results of volatile components are listed in Table 2. Six kinds of compounds were identified, including aldehydes, esters, alcohols, terpenes, aromatics and ketones.

The TIC results (Figure 1) showed that the retention time of the volatile components ranged between 10 and $56 \mathrm{~min}$, most of which were concentrated between 22 mins to 40 mins. Referring to the NIST11.L map library, 36 identical volatile components were confirmed in all the tested samples extracted by SD, UASD and MASD, indicating that extraction method had a minor influence on the varieties of volatiles in the CEO. Moreover, there were three major components in the tested samples, and the remaining components were minor.

Table 2 shows that there were six aldehydes in the volatile components. The relative contents of total aldedydes were $85.104 \%, 86.713 \%$ and $84.447 \%$ for the samples extracted by SD, UASD and MASD, respectively, indicating that aldehydes were the major components in the essential oil. Among the aldehydes, cinnamic aldehyde accounted for the majority of the contents $(73.345 \%, 72.371 \%$ and $67.211 \%$ for SD, UASD and MASD, respectively). Cinnamic aldehyde plays a crucial role in imparting the characteristic flavor to cinnamon (Jayatilaka et al., 1995), and it is a potent natural food preservative due to its antibacterial properties against five common foodborne pathogenic bacteria (Bacillus cereus, Listeria monocytogenes, Staphylococcus aureus, Escherichia coli, and Salmonella anatum) (Rui et al., 2009; Ooi et al., 2006). Apart from cinnamic aldehyde, 2-methoxycinnamaldehyde $\quad(10.611 \%$, 

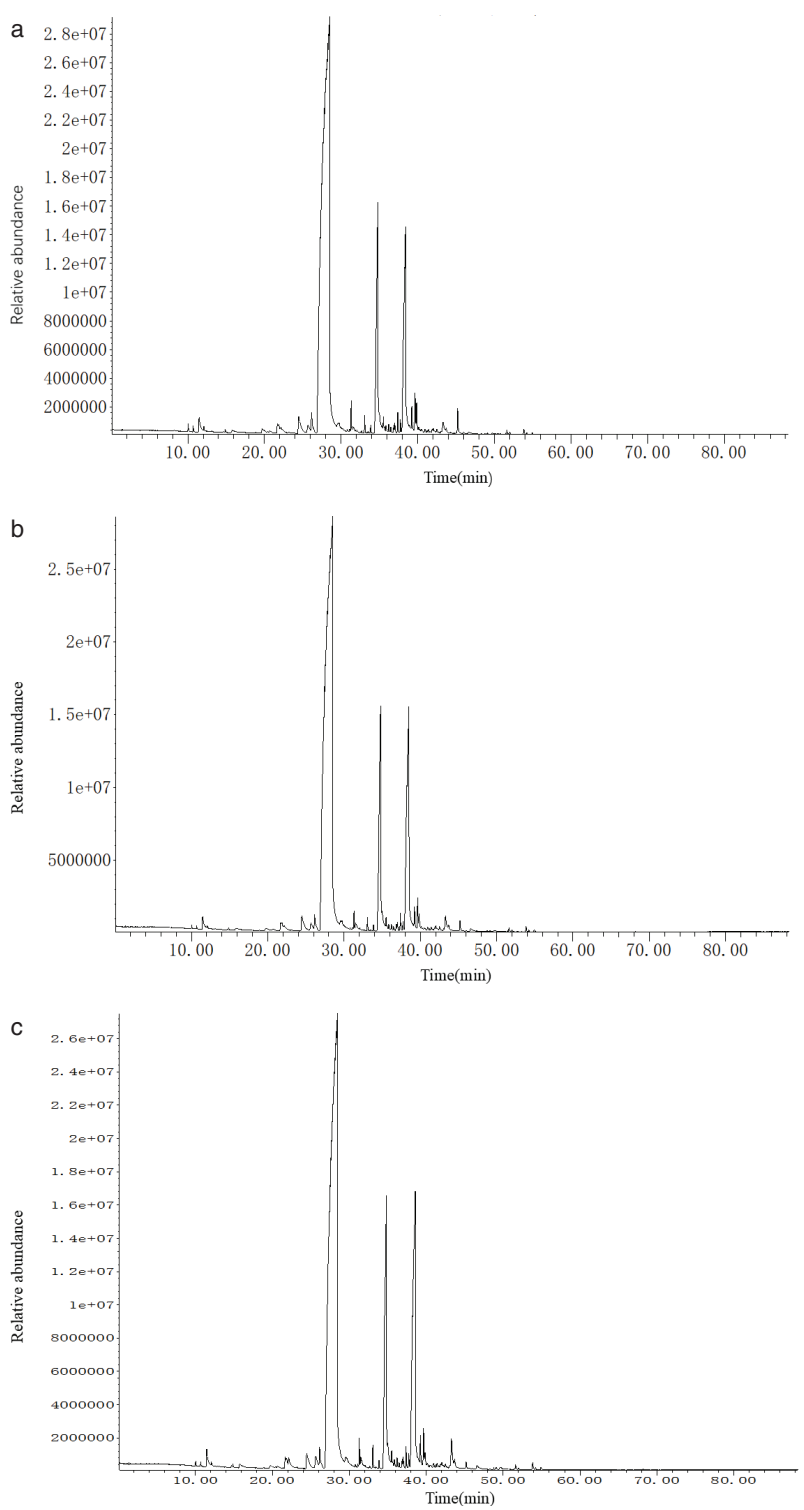

FIGURE 1. Total ion chromatograms (TIC) of cinnamon essential oil extracted by steam distillation (a), ultrasoundassisted steam distillation (b) and microwave -assisted steam distillation(c)

$13.262 \%$ and $15.900 \%$, respectively), benzaldehyde $(0.513 \%, 0.455 \%$ and $0.536 \%$ for SD, UASD and MASD, respectively), and o-anisaldehyde $(0.376 \%$, $0.391 \%$ and $0.531 \%$ for SD, UASD and MASD, respectively) were the other aldehydes were present in high relative contents. Among the above aldehyde components, 2-methoxycinnamaldehyde is considered a crucial component of the unique antibacterial property in CEO (Chang et al., 2001) and a potential agent for anticancer therapy (Wong et al., 2016). The contents of total cinnamic aldehydes (including cinnamic aldehyde and 2-methoxycinnamaldehyde) were $83.956 \%$ (SD), $85.633 \%$ (UASD) and $83.110 \%$
(MASD). Therefore, the highest total content of cinnamic aldehydes was obtained from UASD.

The analytical results were basically consistent with previous works, although there were differences in the number of volatile aldehydes between the present study and earlier studies (Rui et al., 2009; Li et al., 2010), which might be due to different cultivars. Furthermore, it was shown that the MASD extraction method produced the lowest cinnamic aldehyde, but yielded the highest 2-methoxycinnamaldehyde compared with the SD and UASD extraction methods. It might be due to the heating effect of the microwave, which led to the conversion of cinnamic aldehyde in the essential oil to 2-methoxycinnamaldehyde.

Yu et al., found that many esters in cinnamon were valuable packaging materials (Yu et al., 2007). Table 2 shows that three kinds of esters were identified in the CEO extracted by the three methods, i.e., phenylethyl acetate $(0.478 \%, 0.413 \%$, and $0.460 \%$ for SD, UASD and MASD, respectively), cinnamyl acetate $(8.583 \%, 8.210 \%$, and $9.553 \%$ for SD, UASD and MASD, respectively) and benzyl benzoate $(0.094 \%, 0.124 \%$ and $0.152 \%$ for SD, UASD and MASD, respectively). Some researchers found that cinnamyl acetate and phenylethyl acetate were the main volatile substances that impart sweetness, fruitiness, floral aroma, and honey aroma to cinnamon essence ointments (Liet al., 2013). Moreover, the sample with the highest content of total esters $(10.013 \%)$ and cinnamyl acetate $(9.553 \%)$ was the CEO extracted by MASD. According to the report described by Jeyaratnam et al., (2016), it might be attributed to the molecular polarization of the microwave, which leads to the extraction of oxygenates from CEO.

The results showed that there were 7 alcohols and 17 terpenes in the CEO, which is basically consistent with the work by Singh et al., (2007). In summary, 7 alcohols identified from the CEO extracted by SD, UASD and MASD accounted for $2.300 \%, 2.025 \%$ and $2.325 \%$ of the total peak area, respectively; while 17 terpenes accounted for $3.206 \%, 2.260 \%$ and $2.724 \%$, respectively. It was noteworthy that the content of each substance was less than $1 \%$.

Other volatiles in the CEO were aromatics and ketones. The total amount of these compounds was less than $0.3 \%$ in the CEO, but they play vital roles in the aroma, antibacterial and antioxidant properties of CEO. For example, 6-methyl-5-hepten-2-one can endow CEO with the spicy flavor (Luna et al., 2006), which is significant for the aroma of the commercial essence (Alonso et al., 2009). As aromatics have phenolic groups, p-cymene and eugenol could be provided with definite antioxidant activities. In addition, researchers have also discovered that p-cymene is effective in suppressing conidial germination (Hong et al., 2015) and the p-cymene-treated fruit can reduce levels of several anthocyanins 
GC-MS analysis of volatiles in cinnamon essential oil extracted by different methods $\bullet 5$

TABLE 2. Volatile components of cinnamon essential oil extracted by SD, UASD and MASD*

\begin{tabular}{|c|c|c|c|c|c|}
\hline \multirow[b]{2}{*}{ Code } & \multirow[b]{2}{*}{ Components } & \multirow{2}{*}{$\begin{array}{c}\text { Molecular } \\
\text { formula }\end{array}$} & \multicolumn{3}{|c|}{ Relative content $(\%)^{\mathrm{a}}$} \\
\hline & & & SD & UASD & MASD \\
\hline 1 & $\alpha$-Pinene & $\mathrm{C}_{10} \mathrm{H}_{16}$ & $0.092 \pm 0.006$ & $0.042 \pm 0.004$ & $0.054 \pm 0.003$ \\
\hline 2 & Camphene & $\mathrm{C}_{10} \mathrm{H}_{16}$ & $0.078 \pm 0.007$ & $0.037 \pm 0.003$ & $0.048 \pm 0.002$ \\
\hline 3 & Benzaldehyde & $\mathrm{C}_{7} \mathrm{H}_{6} \mathrm{O}$ & $0.513 \pm 0.009$ & $0.455 \pm 0.041$ & $0.536 \pm 0.007$ \\
\hline 4 & $\beta$-Pinene & $\mathrm{C}_{10} \mathrm{H}_{16}$ & $0.107 \pm 0.005$ & $0.044 \pm 0.004$ & $0.090 \pm 0.001$ \\
\hline 5 & 6-Methyl-5-hepten-2-one & $\mathrm{C}_{8} \mathrm{H}_{14} \mathrm{O}$ & $0.016 \pm 0.002$ & $0.008 \pm 0.001$ & $0.012 \pm 0.002$ \\
\hline 6 & $p$-Cymene & $\mathrm{C}_{10} \mathrm{H}_{14}$ & $0.017 \pm 0.003$ & $0.013 \pm 0.002$ & $0.029 \pm 0.002$ \\
\hline 7 & D-limonene & $\mathrm{C}_{10} \mathrm{H}_{16}$ & $0.053 \pm 0.006$ & $0.034 \pm 0.006$ & $0.047 \pm 0.002$ \\
\hline 8 & Salicylaldehyde & $\mathrm{C}_{7} \mathrm{H}_{6} \mathrm{O}_{2}$ & $0.122 \pm 0.002$ & $0.131 \pm 0.001$ & $0.165 \pm 0.001$ \\
\hline 9 & Phenethyl alcohol & $\mathrm{C}_{8} \mathrm{H}_{10} \mathrm{O}$ & $0.202 \pm 0.005$ & $0.168 \pm 0.003$ & $0.151 \pm 0.004$ \\
\hline 10 & Phenylpropyl aldehyde & $\mathrm{C}_{9} \mathrm{H}_{10} \mathrm{O}$ & $0.205 \pm 0.005$ & $0.180 \pm 0.001$ & $0.217 \pm 0.005$ \\
\hline 11 & Borneol & $\mathrm{C}_{10} \mathrm{H}_{18} \mathrm{O}$ & $0.268 \pm 0.004$ & $0.242 \pm 0.002$ & $0.255 \pm 0.002$ \\
\hline 12 & Cinnamic alcohol & $\mathrm{C}_{9} \mathrm{H}_{10} \mathrm{O}$ & $0.319 \pm 0.002$ & $0.311 \pm 0.002$ & $0.435 \pm 0.002$ \\
\hline 13 & Alpha terpineol & $\mathrm{C}_{10} \mathrm{H}_{18} \mathrm{O}$ & $0.031 \pm 0.005$ & $0.038 \pm 0.003$ & $0.020 \pm 0.004$ \\
\hline 14 & Cinnamic aldehyde & $\mathrm{C}_{9} \mathrm{H}_{8} \mathrm{O}$ & $73.345 \pm 0.005$ & $72.371 \pm 0.004$ & $67.211 \pm 0.010$ \\
\hline 15 & $o$-Anisaldehyde & $\mathrm{C}_{8} \mathrm{H}_{8} \mathrm{O}_{2}$ & $0.376 \pm 0.005$ & $0.391 \pm 0.006$ & $0.531 \pm 0.010$ \\
\hline 16 & Phenyl ethyl acetate & $\mathrm{C}_{10} \mathrm{H}_{12} \mathrm{O}_{2}$ & $0.478 \pm 0.003$ & $0.413 \pm 0.006$ & $0.460 \pm 0.005$ \\
\hline 17 & Trans -2-decenal & $\mathrm{C}_{10} \mathrm{H}_{18} \mathrm{O}$ & $0.137 \pm 0.004$ & $0.103 \pm 0.004$ & $0.104 \pm 0.003$ \\
\hline 18 & Cyclosativene & $\mathrm{C}_{15} \mathrm{H}_{24}$ & $0.025 \pm 0.002$ & $0.018 \pm 0.002$ & $0.028 \pm 0.003$ \\
\hline 19 & $\alpha$-Ylangene & $\mathrm{C}_{15} \mathrm{H}_{24}$ & $0.044 \pm 0.001$ & $0.043 \pm 0.003$ & $0.045 \pm 0.005$ \\
\hline 20 & $\alpha$-Copaene & $\mathrm{C}_{15} \mathrm{H}_{24}$ & $0.341 \pm 0.001$ & $0.209 \pm 0.002$ & $0.266 \pm 0.002$ \\
\hline 21 & Eugenol & $\mathrm{C}_{10} \mathrm{H}_{12} \mathrm{O}_{2}$ & $0.202 \pm 0.003$ & $0.234 \pm 0.006$ & $0.298 \pm 0.007$ \\
\hline 22 & $\beta$-Elemene & $\mathrm{C}_{15} \mathrm{H}_{24}$ & $0.027 \pm 0.001$ & $0.022 \pm 0.003$ & $0.025 \pm 0.002$ \\
\hline 23 & Caryophyllene & $\mathrm{C}_{15} \mathrm{H}_{24}$ & $0.227 \pm 0.007$ & $0.170 \pm 0.001$ & $0.250 \pm 0.007$ \\
\hline 24 & $\alpha$-Himachalene & $\mathrm{C}_{15} \mathrm{H}_{24}$ & $0.109 \pm 0.001$ & $0.087 \pm 0.002$ & $0.091 \pm 0.007$ \\
\hline 25 & Cinnamyl acetate & $\mathrm{C}_{11} \mathrm{H}_{12} \mathrm{O}_{2}$ & $8.583 \pm 0.353$ & $8.210 \pm 0.009$ & $9.553 \pm 0.006$ \\
\hline 26 & 2-Methoxycinnamaldehyde & $\mathrm{C}_{10} \mathrm{H}_{10} \mathrm{O}_{2}$ & $10.61 \pm 0.271$ & $13.262 \pm 0.006$ & $15.900 \pm 0.353$ \\
\hline 27 & $\gamma$-Muurolene & $\mathrm{C}_{15} \mathrm{H}_{24}$ & $0.451 \pm 0.002$ & $0.365 \pm 0.002$ & $0.407 \pm 0.001$ \\
\hline 28 & $\alpha$-Muurolene & $\mathrm{C}_{15} \mathrm{H}_{24}$ & $0.232 \pm 0.003$ & $0.186 \pm 0.004$ & $0.244 \pm 0.005$ \\
\hline 29 & $\alpha$-Curcumene & $\mathrm{C}_{15} \mathrm{H}_{24}$ & $0.194 \pm 0.002$ & $0.160 \pm 0.002$ & $0.205 \pm 0.007$ \\
\hline 30 & $\beta$-Bisabolene & $\mathrm{C}_{15} \mathrm{H}_{24}$ & $0.136 \pm 0.002$ & $0.084 \pm 0.002$ & $0.127 \pm 0.003$ \\
\hline 31 & $\delta$-Cadinene & $\mathrm{C}_{15} \mathrm{H}_{24}$ & $0.324 \pm 0.001$ & $0.258 \pm 0.003$ & $0.283 \pm 0.007$ \\
\hline 32 & $\alpha$-Longipinene & $\mathrm{C}_{15} \mathrm{H}_{24}$ & $0.190 \pm 0.001$ & $0.146 \pm 0.004$ & $0.198 \pm 0.004$ \\
\hline 33 & Nerolidol & $\mathrm{C}_{15} \mathrm{H}_{26} \mathrm{O}$ & $0.537 \pm 0.007$ & $0.496 \pm 0.006$ & $0.591 \pm 0.007$ \\
\hline 34 & Spathulenol & $\mathrm{C}_{15} \mathrm{H}_{24} \mathrm{O}$ & $0.738 \pm 0.035$ & $0.590 \pm 0.030$ & $0.656 \pm 0.036$ \\
\hline 35 & Globulol & $\mathrm{C}_{15} \mathrm{H}_{26} \mathrm{O}$ & $0.576 \pm 0.007$ & $0.355 \pm 0.006$ & $0.316 \pm 0.007$ \\
\hline 36 & Benzyl benzoate & $\mathrm{C}_{14} \mathrm{H}_{12} \mathrm{O}_{2}$ & $0.094 \pm 0.006$ & $0.124 \pm 0.003$ & $0.152 \pm 0.004$ \\
\hline
\end{tabular}

*SD (steam distillation); UASD (ultrasound-assisted steam distillation); MASD (microwave-assisted steam distillation). ${ }^{2}$ Each value was expressed as mean \pm standard deviation $(n=3)$

without any phytotoxic effect (Kordali et al., 2008), which might contribute to its overall antioxidant capacity. Moreover, eugenol is the main substance in C. zeylanicum leaf oil, C. pauciflorum leaf oil and C. burmannii leaf oil, which were found to exhibit strong antibacterial effects (Ali et al.,2005) and nematicidal activity (Park et al., 2007).

\subsection{Results of principal component analysis}

The principal component analysis (PCA) has been widely applied in data mining to investigate the underlying structure and to extract the maximum information from large data matrices, so as to preserve as much complete data as possible (Lopez et al., 2007). 
In this work, PCA was carried out to interpret the differences in the volatile components of CEO extracted by SD, UASD and MASD. Table 3 lists 22 major components of the tested samples. Table 4 shows that the cumulative contribution percent of variance of the first two principal components (Eigen values $>1$ ) was $97.744 \%$, where the first principal component accounted for $55.666 \%$ and the second principal component accounted for $42.078 \%$. The first principal component was found to be significantly relevant to phenyl ethyl acetate (0.997), borneol (0.973) and $\gamma$-muurolene (0.966), while the second principal component was strongly characterized by salicylaldehyde (0.996), cinnamic aldehyde (0.995), o-anisaldehyde (0.993) and eugenol (0.991).
Figure 2 (loading plot) and Figure 3 (scores plot) show the score distribution of the first two principal components. Both figures show clear separations among the CEO extracted by SD, UASD and MASD. The PCA figure of SD was positioned at the lower right quadrant of the biplot, which was characterized by globulol, phenethylalcohol and $\delta$-cadinene, compared to UASD and MASD. The MASD was positioned at the upper left area of the score plot and close to the positive half of second principal component, dominated by the presence of cinnamyl alcohol and $o$-anisaldehyde. The components obtained by UASD appeared on the score map in the lower left area with cinnamic aldehyde.

TABLE 3. Loadings of volatiles in the first two principal components

\begin{tabular}{|c|c|c|c|c|}
\hline \multirow[b]{2}{*}{ Compounds } & \multicolumn{2}{|c|}{ Component matrix Component } & \multicolumn{2}{|c|}{ Rotated component Matrix ${ }^{b}$} \\
\hline & 1 & 2 & 1 & 2 \\
\hline Benzaldehyde & 0.916 & 0.065 & 0.760 & 0.516 \\
\hline Salicylaldehyde & 0.615 & -0.784 & -0.002 & 0.996 \\
\hline Phenethyl alcohol & -0.130 & 0.983 & 0.506 & -0.853 \\
\hline Phenylpropyl aldehyde & 0.993 & 0.025 & 0.796 & 0.595 \\
\hline Borneol & 0.647 & 0.751 & 0.973 & -0.190 \\
\hline Cinnamic alcohol & 0.789 & -0.604 & 0.247 & 0.963 \\
\hline Cinnamic aldehyde & -0.651 & 0.754 & -0.045 & -0.995 \\
\hline o-Anisaldehyde & 0.706 & -0.707 & 0.117 & 0.993 \\
\hline Phenyl ethyl acetate & 0.818 & 0.573 & 0.997 & 0.056 \\
\hline$\alpha$-Copaene & 0.574 & 0.808 & 0.951 & -0.280 \\
\hline Eugenol & 0.520 & -0.852 & -0.118 & 0.991 \\
\hline Caryophyllene & 0.994 & 0.062 & 0.819 & 0.566 \\
\hline Cinnamyl acetate & 0.894 & -0.380 & 0.467 & 0.851 \\
\hline 2-Methoxy cinnamaldehyde & 0.358 & -0.918 & -0.287 & 0.942 \\
\hline$\gamma$ - Muurolene & 0.625 & 0.768 & 0.966 & -0.216 \\
\hline$\alpha$-Muurolene & 0.987 & 0.147 & 0.866 & 0.496 \\
\hline$\alpha$-Curcumene & 0.998 & 0.108 & 0.843 & 0.527 \\
\hline$\delta$-Cadinene & 0.539 & 0.839 & 0.942 & -0.326 \\
\hline$\alpha$-Longipinene & 0.973 & 0.197 & 0.886 & 0.447 \\
\hline Nerolidol & 0.968 & -0.251 & 0.605 & 0.796 \\
\hline Spathulenol & 0.603 & 0.743 & 0.933 & -0.211 \\
\hline Globulol & 0.044 & 0.999 & 0.653 & -0.757 \\
\hline
\end{tabular}

${ }^{\mathrm{b}}$ Rotation converged in triplicate.

TABLE 4. Percentage of variance and cumulative variance explained by the principal components

\begin{tabular}{|c|c|c|c|c|c|c|c|c|c|}
\hline \multirow[b]{2}{*}{ Component } & \multicolumn{3}{|c|}{ Initial eigen values } & \multicolumn{3}{|c|}{ Extraction sums squared loadings } & \multicolumn{3}{|c|}{ Rotation sums of squared loadings } \\
\hline & Total & $\begin{array}{l}\text { Percentage } \\
\text { of variance }\end{array}$ & $\begin{array}{l}\text { Cumulative } \\
\text { percentage }\end{array}$ & Total & $\begin{array}{l}\text { Percentage } \\
\text { of variance }\end{array}$ & $\begin{array}{l}\text { Cumulative } \\
\text { percentage }\end{array}$ & Total & $\begin{array}{l}\text { Percentage } \\
\text { of variance }\end{array}$ & $\begin{array}{l}\text { Cumulative } \\
\text { percentage }\end{array}$ \\
\hline 1 & 12.247 & 55.666 & 55.666 & 12.247 & 55.666 & 55.666 & 11.102 & 50.464 & 50.454 \\
\hline 2 & 9.257 & 42.078 & 97.744 & 9.257 & 42.078 & 97.744 & 10.402 & 47.281 & 97.744 \\
\hline
\end{tabular}




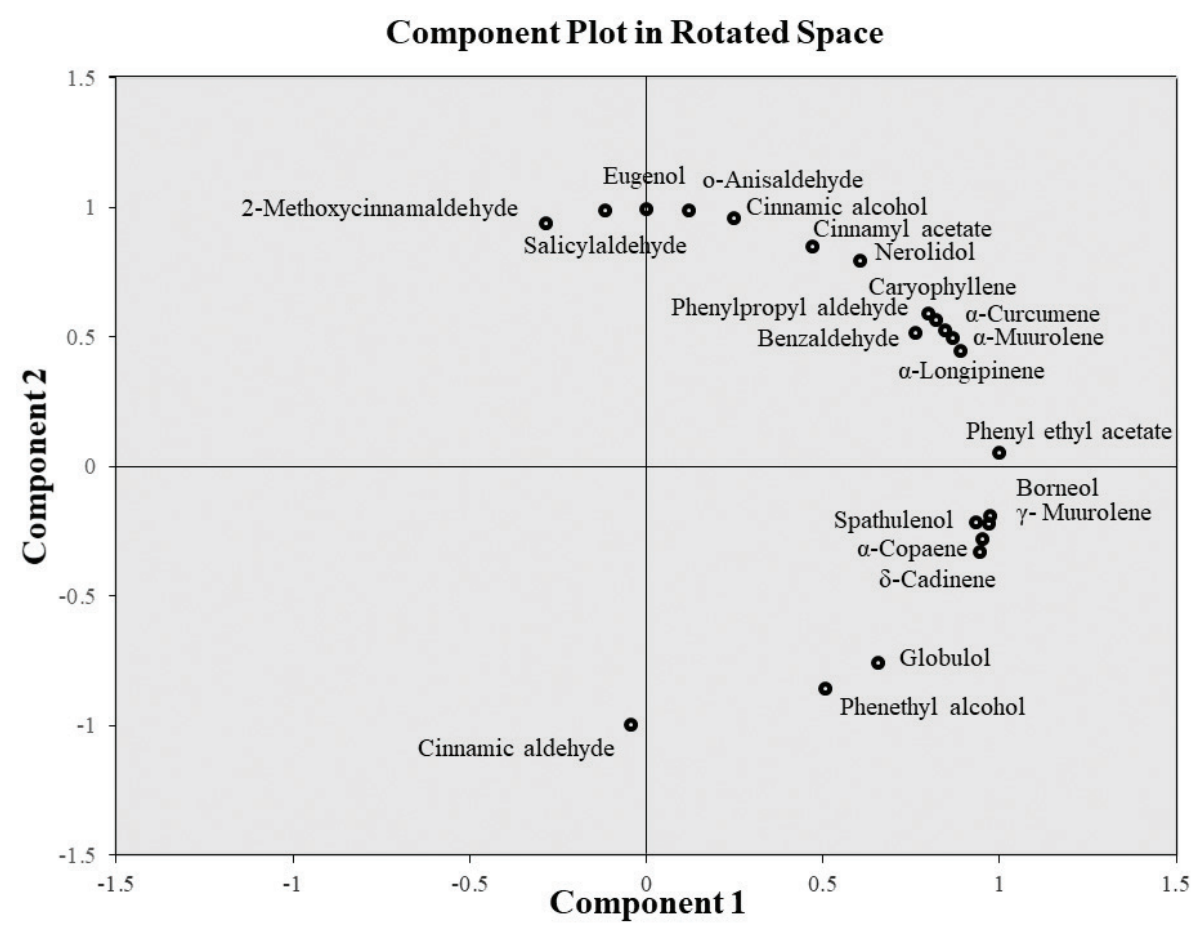

FIGURE 2. Loading plots after principal components analysis of the variables in the plane defined by the two first principal components.

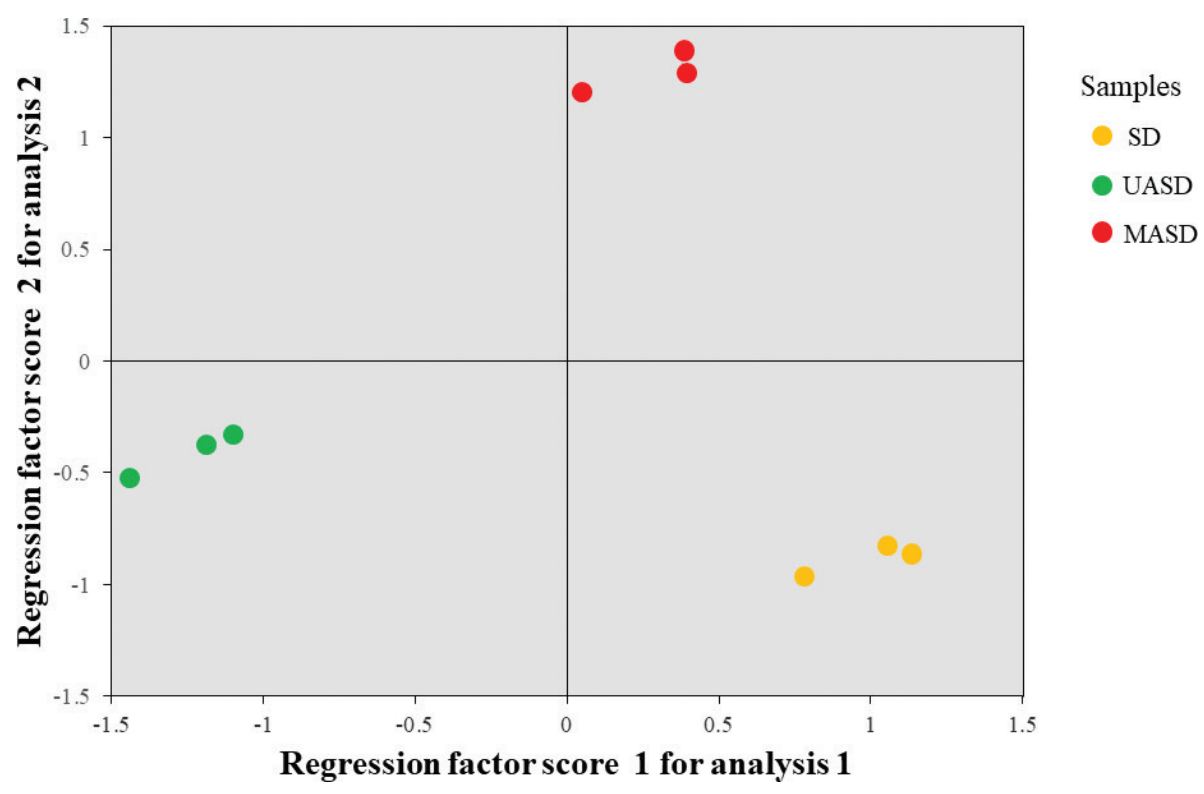

FIGURE 3. Scatter plot of scores via principal component analysis on the individuals in the plane defined by the two first principal components*

*SD (steam distillation); UASD (ultrasound-assisted steam distillation); MASD (microwave-assisted steam distillation) 


\section{CONCLUSIONS}

36 kinds of volatile components were identified in CEO. UASD contained the highest content of total cinnamic aldehydes and the highest yield compared to the SD and MASD methods. Therefore, the UASD method is recommended for future industrial application.

\section{ACKNOWLEDGEMENTS}

This project was financially supported by the Project of Science and Technology of the Guangdong Province of China (Grant No. 2016A020210010, 2016B090923016); Natural Science Foundation of Guangdong Province, China (2018A030313026); the Fundamental Research Funds for the Central Universities (2019MS098). The authors gratefully acknowledge the support of Jinxuan Cao, Huihua Huang and Jin Liao during the development of this scientific work.

\section{REFERENCES}

Ali SM, Khan AA, Ahmed I, Musaddiq M, Ahmed KS, Polasa, H. 2005. Antimicrobial activities of Eugenol and Cinnamaldehyde against the human gastric pathogen Helicobacter pylori. Ann. Clin. Microbiol. Antimicrob. 4, 20. https://doi.org/10.1186/1476-0711-4-20

Alonso A, Vázquez-Araújo L, García-Martínez S, Ruiz JJ, Carbonell-Barrachina ÁA. 2009. Volatile compounds of traditional and virus-resistant breeding lines of Muchamiel tomatoes. Eur. Food Res. Technol. 230, 315-323. https:// doi.org/10.1007/s00217-009-1173-2

Azlina, MF, Hasfalina CM, Zurina ZA, Hishamuddin, J. 2013. Optimization and kinetic study of gaharu oil extraction. Int. Sch. Sci. Res. Innov. 7, 454457.

Chang KS, Tak JH, Kim SI, Lee WJ, Ahn YJ. 2010. Repellency of Cinnamomum cassia bark compounds and cream containing cassia oil to Aedesaegypti (diptera: culicidae) under laboratory and indoor conditions. Pest. Manag. Sci. 62, 1032-1038. https://doi.org/10.1002/ps. 1268

Chang ST, Chen PF, Chang SC. 2001. Antibacterial activity of leaf essential oils and their constituents from Cinnamomum osmophloeum. J. Ethnopharmacol. 77, 123-127. https://doi.org/10.1016/S0378-8741(01)00273-2

Cravotto G, Boffa L, Mantegna S, Perego P, Avogadro M, Cintas P. 2008. Improved extraction of vegetable oils under high-intensity ultrasound and/or microwaves. Ultrason. Sonochem. 15, 898-902. https://doi.org/10.1016/j. ultsonch.2007.10.009

Golmakani MT, Rezaei K. 2010. Microwave-assisted hydrodistillation of essential oil from zataria multiflora boiss. Eur: J. Lipid Sci. Technol. 110, 448-454. https://doi.org/10.1002/ ejlt.200700239

Hong JK, Yang HJ, Jung H, Yoon DJ, Sang MK, Jeun YC. 2015. Application of volatile antifungal plant essential oils for controlling pepper fruit anthracnose by Colletotrichum gloeosporioides. Plan. Pathol. J. 31, 269-277. https://doi. org/10.5423/PPJ.OA.03.2015.0027

Jayatilaka A, Poole SK, Poole CF, Chichila TM. 1995. Simultaneous micro steam distillation/solvent extraction for the isolation of semivolatile flavor compounds from cinnamon and their separation by series coupled-column gas chromatography. Anal.Chim. Acta 302, 147-162. https://doi.org/10.1016/0003-2670(94)00445-R

Jeyaratnam N, Nour AH, Kanthasamy R, Nour AH, Yuvaraj AR, Akindoyo JO. 2016. Essential oil from Cinnamomum cassia bark through hydrodistillation and advanced microwave assisted hydrodistillation. Ind. Crops Prod. 92, 57-66. https://doi.org/10.1016/j.indcrop.2016.07.049

Kordali S, Cakir A, Ozer H, Cakmakci R, Kesdek M, Mete E. 2008. Antifungal, phytotoxic and insecticidal properties of essential oil isolated from Turkish Origanum acutidens and its three components, carvacrol, thymol and p-cymene. Bioresour. Technol. 99, 8788-8795. https://doi.org/10.1016/j. biortech.2008.04.048

Li R, Wang Y, Jiang ZT, Jiang S. 2010. Chemical composition of the essential oils of Cinnamomum loureirii Nees. From China obtained by hydrodistillation and microwaveassisted hydrodistillation. J. Essent. Oil Res. 22, 129-131. https://doi.org/10.1080/10412905.2010.9700281

Li YQ, Kong DX, Wu H. 2013. Analysis and evaluation of essential oil components of cinnamon barks using GCMS and FTIR spectroscopy. Ind. Crops Prod. 41, 269-278. https://doi.org/10.1016/j.indcrop.2012.04.056

Lopez P, Sanchez C, Batlle R, Nerín C. 2007. Vapor-phase activities of cinnamon, thyme, and oregano essential oils and key constituents against foodborne microorganisms. J. Agric. Food Chem. 55, 4348-4356. https://doi.org/ $10.1021 / \mathrm{jf0} 03295 \mathrm{u}$

Luna G, Morales MT, Aparicio R. 2006. Characterisation of 39 varietal virgin olive oils by their volatile compositions. Food Chem. 98, 243-252. https://doi.org/10.1016/j. foodchem.2005.05.069

Matan N, Rimkeeree H, Mawson AJ, Chompreeda P, Haruthaithanasan V, Parker M. 2006. Antimicrobial activity of cinnamon and clove oils under modified atmosphere conditions. Int. J. Food Microbiol. 107, 180-185. https:// doi.org/10.1016/j.ijfoodmicro.2005.07.007

Nabavi S, Di LA, Izadi M, Sobarzo-Sánchez E, Daglia, M. 2015. Antibacterial effects of cinnamon: From farm to food, cosmetic and pharmaceutical industries. Nutrients 7 , 7729-7748. https://doi.org/10.3390/nu7095359

Ooi LS, Li Y, Kam SL, Wang H, Wong EY, Ooi VE. 2006. Antimicrobial activities of cinnamon oil and cinnamaldehyde from the Chinese medicinal herb Cinnamomum cassia Blume. Am. J. Chin. Med. 34, 511-522. https://doi. org/10.1142/S0192415X06004041

Park IK, Kim J, Lee SG, Shin SC. 2007. Nematicidal activity of plant essential oils and components from ajowan (Trachyspermum ammi), allspice (Pimentadioica) and litsea (Litseacubeba) essential oils against pine wood nematode (Bursaphelenchus xylophilus). J. Nematol. 39, 275-279.

Rui W, Wang R, Bao Y. 2009. Extraction of essential oils from five cinnamon leaves and identification of their volatile compound compositions. Innovative Food Sci. Emerg. Technol. 2, 289-292. https://doi.org/10.1016/j.ifset.2008.12.002

Singh G, Maurya S, Delampasona MP, Catalan CAN. 2007. A comparison of chemical, antioxidant and antimicrobial studies of cinnamon leaf and bark volatile oils, oleoresins and their constituents. Food Chem. Toxicol. 45, 0-1661. https://doi.org/10.1016/j.fct.2007.02.031

Wong HY, Tsai KD, Liu, YH, Yang SM, Chen TW, Cherng J, Cherng JM. 2016. Cinnamomum verum component 2-methoxycinnamaldehyde: A novel anticancer agent with both anti-topoisomerase I and II activities in human lung adenocarcinoma a549 cells in vitro and in vivo. Phytother. Res. 30, 331-340. https://doi.org/10.1002/ptr.5536

Wong YC, Ahmad-Mudzaqqir MY, Wan-Nurdiyana WA. 2014. Extraction of essential oil from cinnamon (Cinnamomum zeylanicum). Orient J. Chem. 30, 37-47.

Yu LI, Huang GC. 2007. Microwave assisted synthesis and application of cinnamic esters on packaging materials. Packaging Eng. 28, 34-36. 